\title{
Implicit Criteria Employed by Psychotherapists in Clinical Case Formulation
}

\author{
Francisco Nicolas Di Persia ${ }^{1}$ (D) https://orcid.org/0000-0002-9144-463X
}

\begin{abstract}
From a perspective of common factors implicit criteria used by psychotherapists are explored at the moment of making clinical formulations. It is intended to show the relevance of these criteria for psychotherapeutic practice. The aim of this study was to identify and describe implicit criteria in the clinical formulation process. Methodology: qualitative approach; grounded theory. Participants: 9 psychotherapists with different levels of experience and theoretical approaches that worked with different populations. Procedure: open interviews, in depth transcription and elaboration of results with support of computer software Atlas.ti (5.0). Results: When formulating a clinical case psychotherapists use, together with their theoretical frameworks, a series of implicit criteria (personal identity, adjustment to the medium and intelligibility of the action) inherent to the psychotherapeutic process, originated in interpersonal aspects and organized in reasoning schemes. Conclusion: a novel perspective is proposed for the investigation of the psychotherapeutic process highlighting the social framework that underlies clinical practice.
\end{abstract}

Keywords: psychotherapy, interview, clinical diagnosis

\section{Critérios Implícitos Utilizados por Psicoterapeutas na Formulação de Casos Clínicos}

\begin{abstract}
Resumo:A partir de uma perspectiva de fatores comuns, os critérios implícitos usados pelos psicoterapeutas são explorados ao fazer formulações clínicas a fim de mostrar a relevância desses critérios para a prática psicoterapêutica. Este estudo teve como objetivo identificar e descrever critérios implícitos no processo de formulação clínica. Método: abordagem qualitativa; teoria fundamentada. Participantes: 9 psicoterapeutas com diferentes níveis de experiência e abordagens teóricas que trabalharam com diferentes populações. Procedimentos: entrevistas abertas em profundidade, transcrição e elaboração de resultados com suporte de software de computador Atlas.ti (5.0). Resultado: ao formular um caso clínico, os psicoterapeutas utilizam, juntamente com seus referenciais teóricos, uma série de critérios implícitos (identidade pessoal, ajuste ao ambiente e inteligibilidade da ação) inerente ao processo psicoterapêutico, originado em aspectos interpessoais e organizado em esquemas de raciocínio. Conclusões: uma nova perspectiva é proposta para a investigação do processo psicoterapêutico, destacando a estrutura social subjacente à prática clínica.
\end{abstract}

Palavras-chave: psicoterapia, entrevista, diagnóstico clínico

\section{Criterios Implícitos Empleados por Psicoterapeutas en la Formulación de Casos Clínicos}

\begin{abstract}
Resumen: Desde una perspectiva de factores comunes son explorados criterios implícitos empleados por psicoterapeutas al momento de realizar formulaciones clínicas. Se pretende mostrar la relevancia de dichos criterios para la práctica psicoterapéutica. El objetivo de este estudio fue identificar y describir criterios implícitos en el proceso de formulación clínica. Metodología: enfoque cualitativo; teoría fundamentada. Participantes: 9 psicoterapeutas con distintos niveles de experiencia y enfoques teóricos que se desempeñaban con diversas poblaciones. Procedimientos: entrevistas abiertas en profundidad, transcripción y elaboración de resultados con apoyo de software informático Atlas.ti (5.0). Resultados: al formular un caso clínico los psicoterapeutas emplean, junto a sus marcos teóricos, una serie de criterios implícitos (identidad personal, ajuste al medio e inteligibilidad de la acción) inherentes al proceso psicoterapéutico, originados en aspectos interpersonales y organizados en esquemas de razonamiento. Conclusiones: se propone una perspectiva novedosa para la investigación del proceso psicoterapéutico poniendo de relieve el marco social que subyace a la práctica clínica.
\end{abstract}

Palabras clave: psicoterapia, entrevista, diagnóstico clínico

${ }^{1}$ Universidad Nacional de Córdoba, Córdoba, Argentina

Support: This article was derived from the author's Graduate in Psychology thesis, which was defended in 2012 at the Facultad de Psicología, Universidad Nacional de Córdoba (UNC). Special thanks to Adriana Lanzarotta and Noelia Battellino for their contributions and collaboration.

Correspondence address: Francisco Nicolás Di Persia. Universidad Nacional de Córdoba, Córdoba, Argentina. E-mail: nicodipersia@gmail.com
The investigation of the psychotherapeutic process tries to respond to a series of aspects of great relevance for clinical practice. With this purpose it addresses basic questions of practice that are part of a professional know-how not always explicit.

In a clinical setting, reference theories guide the actions of the professional and explain the relevant clinical facts 
(Krause \& Altimir, 2016). However, as we intend to show in this paper, not all the actions and decisions of the clinician are guided by his theory of adherence. In this sense, certain "gaps" have been marked as not guided by formalized knowledge (González Bravo, 2009, p. 93). The question then lies in knowing how the psychotherapist "fills" the gaps that theory leaves.

It is important to conceive psychotherapeutic practice as an area of interpersonal action in which knowledge oriented towards therapeutic purposes is displayed. The objectives set will be oriented, along with the guidelines derived from the theoretical framework of reference, for ideas of personal well-being, mental health and the reduction of psychic conflicts, among others. The therapeutic results will be based on the occurrence of certain binding elements of the "help" offered by the therapist, such as trust and openness to change (Krause, 2005; Laín Entralgo, 1964).

Based on empirical studies, it has been known that psychotherapists often use criteria to make decisions and establish clinical judgments that do not respond to the guidelines set by their theoretical model of adherence. Among them, the presence of "popular" type knowledge has been highlighted. Studies focused on therapeutic results have been carried out comparing the performance of samples of professional and non-professional (lay) participants obtaining similar therapeutic results in both samples (Krause, 2005). Other studies, focusing on diagnostic criteria, found the same type of diagnostic errors replicated in both samples (from professionals and nonprofessionals) when using graphic methods (Chapman \& Chapman, 1967).

Along with this, there is research aimed at determining the degree to which the psychotherapist "adjusts" to the diagnostic criteria established by manuals such as the DSM (American Psychiatric Association [APA], 1995). For example, it has been shown that clinicians, at the time of making clinical judgments, on numerous occasions do not use structured or schematized criteria but proceed by recognition and identification of stereotyped characteristics of typical cases, which when compared with the degree of "representativeness" that a particular case presents offers the therapist a more efficient way to reach a clinical judgment (Berrios \& Marková, 2015; Garb, 1996). In another similar study (Razzouk, Mari, Shirakawa, Wainer, \& Sigulem, 2006), it was intended to explain how experts recognize schizophrenia, under the assumption that a common pattern that could guide the diagnostic process could be found among professionals. However, they found that although psychotherapists coincided in the diagnosis of the same case, the process to achieve it was different in each one. What is striking in both studies is that when psychotherapists were asked about what criteria they said they had followed to establish their clinical or diagnostic judgments, they indicated a particular theoretical or methodological framework although in no case had all the required characteristics been presented. So that if they had used exclusively their theoretical or methodological frameworks then they would not have been able to establish the indicated diagnostic category.
The problem of knowing what criteria are used in various aspects of the psychotherapeutic process is an open question that could clarify relevant elements of clinical practice. The approach adopted in this work was to identify aspects of psychotherapeutic practice that arise spontaneously and naturally from the reports that psychotherapists of different currents and with different training use when they have to characterize their practice and justify assessments and interventions they consider relevant. In this way, it is intended to identify and characterize a background of elementary knowledge that underlies the explanations that clinicians explicitly offer when they perform the clinical formulation of a case. The latter constitutes a challenge in itself, taking into account that psychotherapeutic practice is constantly beset by a prejudice or theoretical bias which influences the professional's own perception of his practice, leading him to offer theoretical foundations and to "translate" a large part of the actions carried out in his practice to his adherence model (Di Persia, 2016, 2017; Laín Entralgo, 1985). In other words, it was argued that what the clinician says he does, does not always reflect what he actually does (Paul, 1973).

The common factor psychotherapy model was adopted because it focuses on the exploration of effective and relevant aspects of the psychotherapeutic process that are shared by different theoretical frameworks, and because it is considered as an important element the presence of implicit criteria that actively work under general objectives that the different psychotherapy models share (Koemeda-Lutz, Crameri, Tschuschke, Schulthess, \& von Wyl, 2016; Krause, 2005; Krause \& Altimir, 2016; Wampold, 2015). Some authors have pointed out among the main implicit criteria the expectations about people and their conflicts, for example: that they may be responsible, permeable to change, that they can establish a working alliance, among others (Kirmayer, 1989; Koemeda-Lutz et al., 2016; Krause, 2011; Lin, 2016; Williams \& Levitt, 2007). In addition, a central element that highlights this model is the therapeutic relationship or helping relationship, considered as a particular way of linking that involves both the psychotherapist and the consultant actively, delineating and guiding the psychotherapeutic process (Di Persia, 2017; Laín Entralgo, 1985).

Based on this model, it was proposed to examine a relevant aspect of the psychotherapeutic process: clinical case formulation. Some authors place it as the central axis because it links theoretical framework with development of the clinical process, and it also functions as a link between diagnosis and treatment (González Bravo, 2009; Restifo, 2010). Clinical formulation is based on hypotheses about the causes or situations that generate and/or sustain the psychological, interpersonal or behavioral problems of a person, as conceived by the psychotherapist. In this way it directly affects the general conception of treatment, planning, interventions and diagnosis (González Bravo, 2009; Sturmey, 2009). The content of clinical formulations incorporates "visions of the therapist's world" (González Bravo, 2009, p. 94), 
which implicitly and explicitly function as a referential framework from which they constructs senses, assessments and judgments. Thus, linked to various notions related to health and disease, normal and pathological, rational and irrational, etc., the clinician, whether they know it or not, applies certain perceptual and reasoning schemes that function as a guiding axes in the therapeutic relationship.

In this way, and in order to investigate these schemes in greater depth, the objective of the study was to identify and describe implicit criteria in the clinical formulation process that allow us to understand how psychotherapists use such criteria when performing a clinical formulation, thus aiming to clarify aspects of psychotherapeutic practice that escape formal knowledge and theoretical prejudices.

\section{Method}

Based on a qualitative model oriented from the general principles of grounded theory (Miles, Huberman, \& Saldaña, 2014; Strauss \& Corbin, 1998), spontaneous descriptions of the psychotherapists about their practice were obtained in order to identify criteria and notions that they use and consider relevant when they make clinical formulations within the framework of the psychotherapeutic process.

\section{Participants}

Nine professionals from the public and private spheres in the province of Córdoba, Argentina who were actively performing clinical practice and had at least two years of experience were intentionally selected. Five psychologists (4 psychoanalysts and 1 cognitive) and 4 physicians (3 psychiatrists and 1 resident of psychiatry) participated, offering a range of diverse theoretical orientations, work environments and relationships with different patient populations.

\section{Instruments}

In-depth open interviews of approximately one hour were conducted based on guiding axes (Figure 1).

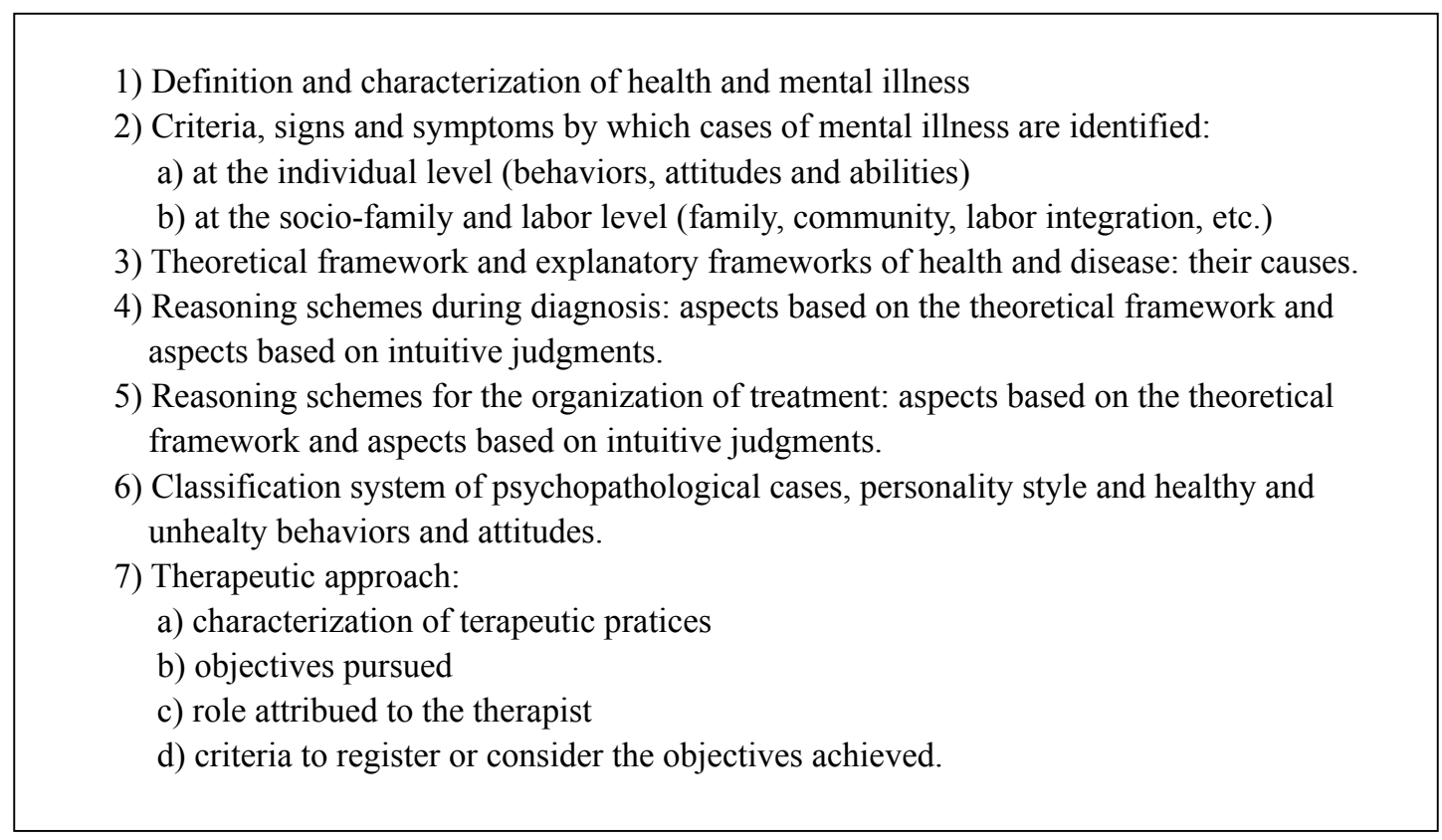

Figure 1. Guiding axes of the interviews.

\section{Procedure}

Data collection. The interviews were conducted by the author of the work and also by members of a research team granted by the Secretariat of Science and Technology (SeCyT) of the Universidad Nacional de Córdoba (UNC). A first pilot interview was conducted in order to adjust the axes and establish a general interview format. Participants were asked to use a variety of clinical formulation resources, such as the evocation of significant clinical scenarios and situations, the use of exemplifications, the conceptualization and substantiation of judgments, assessments and interventions, among others. They were performed in the consulting room of the participants. The material collected was transcribed by the author of the present study with the supervision of the director of the Thesis.

Data analysis. With the support of the Atlas.ti 5.0 software, an open coding of the first interview was carried out in order to prepare the first categories of analysis. As new interviews were analyzed, the category chart was expanded and modified, seeking to generate a saturation criterion. Once all the material was categorized, the linking and associating of the whole set of categories was developed, establishing nuclear categories and subcategories according to the relevance and specificity of their content (Figure 2). 


\begin{tabular}{|c|c|c|}
\hline Open coding & Axial coding & $\begin{array}{l}\text { Selective } \\
\text { codification }\end{array}$ \\
\hline $\begin{array}{l}\text { 1) General notions of health and mental } \\
\text { illness } \\
\text { - Notions linked to the theoretical } \\
\text { framework of reference } \\
\text {-"Practical" descriptions of mental } \\
\text { illness } \\
\text { - Non-specific concepts or notions } \\
\text { - Diagnosis and intervention. } \\
\text { - Behavior Tipification }\end{array}$ & $\begin{array}{c}\text { Subjectivity } \\
\text { Autonomy } \\
\text { Mental health } \\
\text { Identity } \\
\text { Freedom } \\
\text { Responsability }\end{array}$ & $\begin{array}{c}\text { Personal } \\
\text { Identity }\end{array}$ \\
\hline $\begin{array}{l}\text { 2) Health and mental illness assumptions } \\
\text { - Responsability } \\
\text { - Rationality } \\
\text { - Harmony } \\
\text {-Dangerousness }\end{array}$ & $\begin{array}{c}\text { Harmony } \\
\text { Adaptation } \\
\text { Dangerousness }\end{array}$ & $\begin{array}{l}\text { Adjustment } \\
\text { to the social } \\
\text { environment }\end{array}$ \\
\hline $\begin{array}{l}\text { 3) Esquemas de razonamiento clínico } \\
\text { - Responsability and to be conscious } \\
\text { - Rationality } \\
\text { - Harmony } \\
\text { - Dangerousness }\end{array}$ & $\begin{array}{c}\text { Responsability } \\
\text { To be conscious } \\
\text { Rationality }\end{array}$ & $\begin{array}{l}\text { Intelligibility } \\
\text { of the action }\end{array}$ \\
\hline
\end{tabular}

Figure 2. Categorization procedures: open, axial and selective.

\section{Ethical Considerations}

The participants were contacted through a professor from the Faculty of Psychology of the National University of Córdoba. They were briefly informed about the purpose of the interview was and their informed consent was requested.

\section{Results}

Under the name of General notions of health and mental illness, a category was developed that reflected explanations and foundations based on the theories to which the participants adhered. Some examples are highlighted below: "How do you define delirium? I believe... what comes to mind is the classical psychiatric definition, an immovable belief that doesn't agree with reality"; "a reference to the lack of paternal foreclosure that produces psychosis in psychoanalytical theory"; "negative symptoms such as affective blunting, which can lead to physical or motor inhibition. The positive symptoms are hallucinatory, which generally result in emergency medical consultation."

Given this type of response, we sought to strengthen the fundamentals and criteria reported, sometimes adopting a naive and neutral position regarding the various assumptions that were be mentioned. The initial objective was to clarify which specific criteria, both individually and socially, the participant included or associated with the theoretical descriptions. This resulted in responses such as:_"[a child with behavioral problems is] a child that has never had limits"; "we understand madness as the exacerbation of one of the mental faculties or human behaviors; "many issues with anxiety, few social support networks... there is a common denominator in relation to the social context, to the role they have within their social sphere."

These types of responses were categorized as unspecific concepts or notions, since they implied descriptions with less theoretical specification that were shared by the participants. As indicated by expressions such as "limits, exacerbations, in conduct or "role" attributed to the social context", based on these characterizations, the inclusion of nonspecific notions regarding the theoretical adhesion frameworks was observed to exemplify relevant clinical criteria.

As content of this type of criteria was compiled, it became necessary to develop other categories and subcategories that would allow organizing and ordering the various meanings to which these nonspecific criteria referred; this is how the categories were developed: responsibility, rationality, harmony and danger.

Other categories reflected specific theoretical content oriented towards aspects of the psychotherapeutic process such as diagnosis and interventions. Initially it was attempted to separate what were notions of health and illness on the one hand (under the category of assumptions of health and mental illness) and the scope of decisions, interventions and clinical judgments on the other (under the category of Clinical reasoning schemes). However, this distinction did not clearly reflect the mode of reasoning of the participants. An intimate link was observed between both aspects so that what represented an assumption of disease or diagnosis, was then used to support the intervention or action performed. For example, a participant established obsessive rituals as a 
clinically significant aspect, and the description he offered already contained elements that then functioned as intervention criteria, which in that case aimed to minimize the performance of such rituals. Another example was the one referred by another participant who indicated as diagnostic criteria the "negative symptoms: abulia, with apathy, lack of desire, motivation", and linked to these criteria, he said that some of the objectives that an intervention could propose were:

that.. they can say 'no'. That someone in the family will not necessarily consider it an advancement, ... before they were docile and did everything that was asked of them, and now they say no, now they say they don't like to or don't want to.

Another participant similarly reported that "if a child has an expansive or hyperactive tendency there are certain games that can further exalt them", so the design of the therapeutic approach should aim to establish "games that can help to better control conduct".

These fragments exemplify the articulation between notions and assumptions of health and mental illness as well as between interventions and diagnoses based on clinical reasoning schemes; that is, the integrated way in which they are presented in clinical formulation. At this point, the need to understand the articulation between these reasoning schemes and the nonspecific criteria used by the participants (categories of responsibility, rationality, harmony and danger) was raised. The questions asked were aimed at discovering how participants introduce nonspecific criteria into their reasoning schemes when they perform a clinical formulation. In the analysis it became clear that the answer should be practical, that is, the purpose of using the nonspecific criteria should be understood. Thus, according to the main areas which they reported: individual, social, and rational, three nuclear categories were formed: personal identity (notions related to subjectivity, autonomy and freedom), adjustment to the environment (adaptation and danger) and intelligibility of the action (rationality, responsibility and conscience).

\section{Personal Identity}

Notions such as subjectivity, responsibility, health and illness were linked to assessments of the patient's personal identity. From there, criteria were used to consider limitations, difficulties or potentialities attributed to the person: "that she can do what she chooses to, start to motivate herself ... a panorama has to appear ... a desire to live for something".

These types of notions framed some of the basic objectives proposed:

patients that come for a consult but do not have a clear demand, they come for solutions to their problems. They do not look within but deposit their search for knowledge with you, they don't recognize that they have the answers"; each one has "a subjective experience about being well and being unwell, ... what is being healthy and what is being sick ... it is this subjective experience that brings the subject to consult.

These types of expressions reflected content usually linked to a positive or negative assessment of life, health and subjectivity: "we see how much the patient's symptoms limit them"; "a subject that in the first consult comes and says ... 'in reality I think that I don't have an identity, I haven't chosen how I am', is not a normal subject".

The idea of their own and other people's well-being, and even the idea of "limits" which were mentioned repeatedly "intervene in the household to construct a limit, to permit the possibility to discriminate, to have something, so that some of the patient's subjectivity appears", were also linked to notions of health and illness: "development ... of their subjectivity", "that one day they can say no ... that something of their own or the possibility to decide appears, to think"; "the lack of dependence".

When these criteria were aimed at children, they were explicitly associated with education or basic rules of behavior:

A child with behavioral problems is a child that has never had limits ... the limits are established since the child is born, I always tell this to the parents. To organize meal time and to organize bed time is a form of limiting. We do not eat every hour, we eat every three. If the child has a change in their normal day, expect one month to slowly change their schedule.

Finally, behind another set of terms like "the will to live", "self affirmation" or "liberty" a series of expectations are expressed. These ideas are based on a vital impulse, an appetitive sense of desire, of will, of motivation for life that the psychotherapist, whether or not aware of, attributes to the consultant and can be seen in expressions such as: "change their role ... as a receptor, that life falls from above, to suddenly realize that they can decide what they want in their life".

The examples presented expose the use of diverse implicit criteria that make up a set of expectations about the person, or the development of personal identity, which constituted the largest number of nonspecific references identified in the psychotherapist's reports.

\section{Adjustment to the social environment}

The use of terms such as "adaptation", "development" and "evolution" is connected with social and community expectations that usually characterize the way in which a person's action is valued in a given environment, placing the emphasis no longer exclusively on the subject but also extending it to its social insertion. As expressed by a participant: "there are internal beliefs that also create barriers so that a child evolves ... When they point fingers (like a disaster) it's difficult for the child to evolve"; "fears, distraction, angst, pity, or whatever it is that inhibits development"; "the child has a maladaptation to their environment and to their reference group and starts to have behaviors or symptoms that show this maladaptation". 
Valuations of this type implicitly support people's social functioning modes: "you can have a psychotic that is doing well and is not sick, because they are fine and are stabilized"; "one avoids the rigidization of a conduct and by some means, stimulates alternatives to be with others".

This set of notions referring to adjustment in the social environment was important for psychotherapists when identifying whether the person was dangerous to himself or others. In general, the participants converged on the idea that the subject should not endanger his life or that of others, and especially psychiatrists saw at this point a relevant criterion: "always evaluate if there are suicide attempts, that are also a criteria for hospitalization".

It is noteworthy that assumptions of this type underline expectations like work, following rules and not harming the interests of the community. These are the so-called institutionalized social expectations (Laín Entralgo, 1985) Interventions are based on these types of notions that aim at "controlling" the behavior and the need for the person to have "self-control" of their actions: "if a child has an expansive or hyperactive tendency ... practice ways to control their conduct"; "always compulsive and aggressive with his wife, ... he had always been very impulsive, I think even physically aggressive. Like he could never control it".

It seems clear that the participants expressed the need for the person to establish a "harmonious" relationship with the environment and a shelter of "life." These manifestations were observed both in diagnostic criteria (impulsiveness, hyperactivity, suicide attempts) and in interventions (forms of control, hospitalization), although they also clearly show non-specificity regarding the theoretical frameworks of psychotherapists.

\section{Intelligibility of the action}

The set of criteria grouped under this category are those that have the most philosophical burden, however, if the purpose they pursue is achieved, their usefulness and the way in which the therapists use them can be clarified. Under the concept of intelligibility of the action, a series of actions aimed at making patients' behavior understandable (Jaspers, 1977) was grouped. This concept refers to a rational framework that is developed when trying to justify the motive or the results of people's actions. In cases where such a rational framework cannot be established, the action in question ceases to be understandable and becomes bizarre, strange or inadequate. This is how a series of acts that are considered irrational establish what in diagnostic terminology characterizes an obsessive ritual: for example, using a whole roll of toilet paper every time they go to the bathroom, changing their pants a certain number of times or washing their hands excessively in an attempt to avoid harm or impose that it exclusively be done this way.

What remains implicit with these types of actions is that the purpose of theses "rituals" is not a specific attribute of the action itself, but instead the rational framework based on which the action is qualified as a ritual defines it as one, and the criterion used by psychotherapists in these cases come from the rational framework that guides and rationalizes these actions because they do not respond to possible justifications. This same criterion was also used by several participants: "when a subject says 'I don't need what they robbed from me, I need what I never had', 'one could say: how could someone miss something they never had?, in order to miss something it must have been there first" "; "a subject that in the first interview comes and says they are worried about their life, they don't have friends, they're always alone, and 'their problem is time management" "; " [a] patient who took ... twenty televisions... from a supermarket, and stopped in a service station to give them away ... If you see them at first you say they are a psychotic".

As these fragments express, these are facts and actions that "at first glance" show a disproportion or alteration with respect to the norm. As previously developed, the diagnosticintervention reasoning scheme was again observed here. In these cases, the intervention that usually complements these judgments of rationality or intelligibility of the action assumes the attempt to frame (rationally) such action and bring it back to a plane of intelligibility, or show the error or lack of reasoning committed.

This reasoning scheme was made evident from criterion such as the "realization" or "conscienceness" of the person: "many people are not conscience of sickness and it is difficult to create the demand"; "psychotic patients that in general come with strong hallucinations, very delirious, become aggressive, or put their life at risk, because they are not conscience of what they do"; even if they are psychotic and not conscience of what is happening, ... "a paranoid episode, in which there is no way for him to realize that his life revolves around the delirium".

These notions about "conscience" implicitly employ criteria of intelligibility of action that are also nonspecific with respect to theoretical frameworks.

\section{Discussion}

Based on the reports that psychotherapists of different currents and with different training use when characterizing their practice and justifying assessments and interventions that they consider relevant implicit criteria were identified that they usually use as elements involved in decisionmaking and the establishment of clinical judgments.

It was also observed that they do not respond to guidelines set by their theoretical adherence model. These criteria contain "popular" knowledge that allows the clinician to complement aspects that his theories cannot cover.

From a model of common factors, we tried to explore criteria that naturally and spontaneously the psychotherapists themselves used when they had to carry out the clinical formulation of their cases. In this way, attempts were made to overcome the generalized theoretical bias that influences the professional's own perception of his practice, leading him to offer theoretical foundations and to "translate" a large part of the actions carried out in his practice to his adherence model. 
Two important aspects can be observed in the organization of the material made. One is linked to the way in which the implicit criteria are used, and the other is linked to the purpose they pursue.

Regarding the form or mode of use of the implicit criteria, it was observed that the professionals initially started with explanations and rationale based on their theories of adherence, and only when some reported criteria were thoroughly questioned, mainly about diagnosis and the interventions carried out, a series of criteria emerged (called nonspecific) that justified, explained and paid a large part of the various actions and decisions formulated by the participants. It was observed in the diagnostic and intervention judgments that these criteria are organized in reasoning schemes and guide a series of basic patterns that include both theoretical and formal knowledge as well as nonspecific criteria and notions.

In relation to the purpose for which psychotherapists used this type of reasoning scheme, a series of general aspects were identified that included notions of personal identity, adjustment to the environment and intelligibility of the action, depending on whether the contents were oriented towards individual, social or rational aspects.

As a whole, it seemed clear that these types of criteria belonged to a "common sense epistemology" (Paicheler, 1979) because they constitute expressions that originate outside the consulting room (Laplantine, 1999), which function as a "tacit scheme" (Laín Entralgo, 1964, p. 261) and that do not respond to the contents of any particular theory. Its origin would respond to the social and cultural framework of reference, which is transferred by the professional, whether he knows it or not - and regardless of its theoretical framework - to the psychotherapeutic field. It is understood in this way why "most of the time the conscious interpretations of disease and healing are nothing more than eminently relative cultural norms and, therefore, do not have the operational character we seek" (Laplantine, 1999, p. 40). These aspects oriented towards the understanding and interaction between therapist and patient direct the practice towards basic therapeutic goals and objectives. Thus, the concept of a "helping relationship" that characterizes the therapeutic link can be understood in full sense.

Based on the form and purpose with which these implicit criteria were used, important aspects of the practice can be clarified. For example, when participants used notions of intelligibility of the action in their stories, it could be seen that what they did implicitly was to display a "charitable" attitude (concept used in folk or popular psychology) (Brunsteins, 2010). This is evidenced by the fact that in those cases where rationality criteria that make the patient's actions understandable are not established, the clinicians used criteria of intelligibility of the action in expressions such as: that the person cannot be aware of their error in the "social world" or adopt another perspective of reality, among others. This natural, charitable attitude, in anthropological terms (close to the perspective of common factors) constitutes an attitude of "help", which became evident in some reports and descriptions in which the participants expressed "satisfaction" and "enthusiasm" when their interventions helped change an established pattern of consciousness or reality in their patients: "the fact that she registers that she is punishing herself is something fantastic. I mean, her level of consciousness in the face of what is happening"; "[it is important that the patient] can see what is happening to them, can recognize that something is happening to them, to be able to start to work".

Rationality criteria such as those mentioned are used as forms of tacit assessment that indicate and guide the professional's understanding of the actions that are considered justified and unjustified (from a rational point of view). And, most importantly, they have a direct influence on the reasoning schemes oriented towards diagnosis and intervention.

Implicit criteria oriented to social framework are those that underlie the assumption that the person can act on the basis of certain institutionalized social expectations such as "developing some virtue, providing a service or developing a profession or employment" (Laín Entralgo, 1964, p. 93). Other criteria of personal identity were used towards the personal and subjective link with respect to the family and one's life, just to mention some of the many examples reported by the participants.

Among the challenges and the potentialities of the approach adopted, together with the results obtained, the importance of considering therapeutic interaction as a "social influence process" (Krause, 2005, p. 41) is highlighted together with the need to pay close attention to subtleties, particularities and the various instances which the interpersonal plane poses to the therapeutic encounter. Highlighting, and even giving an "epistemic priority" to this background (Berrios, 2011a, 2011b), allows us to answer some of the difficulties faced by research that does not warn, or minimizes this aspect of psychotherapeutic practice. Thus, for example, it is understable the difficulties encountered in studies that have sought to consider the diagnostic process as a mode of reasoning guided exclusively by theoretical or methodological criteria such as those of Garb (1996) and those of Razzouk et al. (2006). Instead, the clarification of social aspects linked to therapy has shown that there are prominent elements of the psychotherapeutic process that distance it from the traditional categories, for example those of diagnostics (Krause, 2005), to give a relevant role to diverse clinical formulations elaborated to give an answer to the psychological problems or psychic conflicts that the psychotherapist treats.

In relation to the methodological design, it is a limitation of the study to have only the psychotherapists' reports without direct contact with a real clinical scenario, since in practice various criteria are used that are part of a know-how that is difficult to explain and that usually remain biased. A closer link to practice would provide richer elements of analysis (Adeponle, Groleau, \& Kirmayer, 2015; Botella \& Maestra, 2016; Botella, Maestra, Guillem, Corbella, \& Vall, 2015).

Regarding the sample, several limitations of this study can be pointed out, since psychiatrists and psychologists were included, who, having different training, possibly assign a different weight to the type of implicit criteria formulated 
according to the diverse possibilities and purposes of their practices. It is possible that there is a greater representation of participants adherent to the psychoanalytic model, since there was only one cognitivist, leaving out other theoretical models. Other limitations of the study are the non-specification of the population of patient populations (we worked on general expressions around the practice as a whole) and the undifferentiation of the levels of experience of the participants. Given these limitations, these results should only be considered as a first exploratory approach that should be extended and specified.

Finally, it is interesting to review some reflections expressed by a participant about aspects of his practice that he "had never thought of" before having the interview, in which he said:

A thousand times I think, what enables us ... to do something, ... when a family demands something, and we know that we are not going to do what they want, but what we think is best for the subject; what enables us to interfere in someone's house, knowing that they call us for one thing and we are going to do something else; how do we sustain that?

\section{References}

Adeponle, A., Groleau, D., \& Kirmayer, L. J. (2015). Clinician reasoning in the use of cultural formulation to resolve uncertainty in the diagnosis of psychosis. Culture, Medicine and Psychiatry, 39(1), 16-42. doi:10.1007/s11013-014-9408-5

American Psychiatric Association. (1995). DSM-IV: Manual diagnóstico y estadístico de lostrastornosmentales [DSM-IV: Diagnostic and statistical manual of mental disorders](T. Flores iFomenti, J. T. Trallero, J. M. Ronquillo, J. T. Torres, \& C. U. Abelló, Trans., 4th ed.). Barcelona, España: Masson.

Berrios, G. E. (2011a). Filosofía e historia de la psiquiatría y la psicopatología- 1a parte [Philosophy and history of psychiatry and psychopathology- 1st part]. VERTEXRevista Argentina de Psiquiatría, 22(Supl. 1), 5-30

Berrios, G. E. (2011b). Hacia una nueva epistemología de la psiquiatría [Towards a new epistemologyofpsychiatry]. Buenos Aires, Argentina: Polemos.

Berrios, G. E., \&Marková, I. S. (2015). Towards a new epistemology of psychiatry. In L.J.Kirmayer, R.Lemelson, \& C. A. Cummings (Eds.), Re-visioning psychiatry: Cultural phenomenology, critical neuroscience, and global mental health (pp. 41-64). New York, NY: Cambridge University Press.
Botella, L., \& Maestra, J. (2016). Integración en psicoterapia en terapeutas en formación: Atribución de factores comunes e ingredientes específicos en casos prototípicos de cinco orientaciones psicoterapéuticas [Psychotherapy integration in psychotherapists in training: Attribution of common factors and specific ingredients to prototypical cases of five theoretical approaches]. Revista Argentina de Clínica Psicológica, 25(1), 39-48.

Botella, L., Maestra, J., Guillem, F., Corbella, S., \& Vall, B. (2015). Integración en psicoterapia 2015: Pasado, presente y futuro [Integration in psychotherapy 2015: Past, present and future]. Retrieved from https://www. researchgate.net/publication/284869588_Integracion_ en_psicoterapia_2015_pasado_presente_y_futuro

Brunsteins, P. (2010). La psicología Folk: Teorías, prácticas $y$ perspectivas [Folk psychology: Theories, practices and perspectives]. Buenos Aires, Argentina: Ediciones Del Signo.

Chapman, L. J., \& Chapman, J. P. (1967). Genesis of popular but erroneous psychodiagnostic observations. Journal of Abnormal Psychology, 72(3), 193-204. doi: $10.1037 / \mathrm{h} 0024670$

Di Persia, F. (2016). Aspectos conceptuales y metodológicos involucrados en el campo de investigación del razonamiento diagnóstico [Conceptual and methodological issues involved in the field of research and diagnostic reasoning]. VERTEX-Revista Argentina de Psiquiatría, 27(127),170-176.

Di Persia, F. (2017). Elementos de la relación médico-enfermo relevantes en la práctica psicoterapéutica. Abordaje desde una perspectiva antropológica personalista [Doctorpatient relationship factors involved in psychotherapeutic practice. A personalistic anthropologyc perspective]. Anuario de Investigaciones de la Facultad de Psicología, 3(1), 465-480.

Garb, H. (1996). The representativeness and pastbehavior heuristics in clinical judgement. Professional Psychology: Research and Practice, 27(3), 272-277. doi:10.1037//0735-7028.27.3.272

González Bravo, L. A. (2009). Formulaciones clínicas en psicoterapia [Clinical formulations in psychotherapy]. Terapia Psicológica, 27(1), 93-102.doi:10.4067/S071848082009000100009

Jaspers, K. (1977). Psicopatología general [General psychopathology] (R. O. Saubidet \& D. A. Santillán, Trans., 4th ed.). Buenos Aires, Argentina: Beta.

Kirmayer, L. J. (1989). Psychotherapy and the cultural concept of the person. Santé, Culture, Health, 6(3), 241-270. 
Koemeda-Lutz, M., Crameri, A., Tschuschke, V., Schulthess, P., \& von Wyl, A. (2016). Therapists' interventions in different psychotherapy approaches: Category and temporal aspects. International Body Psychotherapy Journal. The Art and Science of Somatic Praxis, 15(2), 37-65.

Krause, M. (2005). Psicoterapia y cambio: Una mirada desde la subjetividad [Psychotherapy and change: An outlook from subjectivity]. Santiago, Chile: Ediciones Universidad Católica de Chile.

Krause, M. (2011). La Psicoterapia: ¿Oficio sin Ciencia y Ciencia sin Oficio? [Psychotherapy: Practice without Science or Science without Practice?]. Revista Colombiana de Psicología, 20(1), 89-98. Retrieved from http://www.scielo.org.co/scielo.php?script=sci_ arttext\&pid $=$ S0121-54692011000100007

Krause, M., \& Altimir, C. (2016). Introduction: Current developments in psychotherapy process research. Estudios de Psicología, 37(2-3), 201-225. doi:10.1080/ 02109395.2016.1227574

Laín Entralgo, P. (1964). La relación médico-enfermo: Historia y teoría [Sick-physician relationship: History and theory]. Madrid, España: Revista de Occidente.

Laín Entralgo, P. (1985). Antropología médica para clínicos [Medical anthropology for clinicians]. Barcelona, España: Salvat.

Laplantine, F. (1999). Antropología de la enfermedad [Anthropology of sickness]. Buenos Aires, Argentina: Ediciones del Sol.

Lin, Y.-N. (2016). The framework for integrating common and specific factors in therapy: A resolution. International Journal of Psychology and Counselling, 8(7), 81-95. doi:10.5897/IJPC2016.0398

Miles, M., Huberman, A. M., \& Saldaña, J. (2014). Qualitative data analysis: A methods sourcebook. Los Angeles, CA: Sage.

Paicheler, H. (1979). La epistemología del sentido común [The common sense epistemology]. In S. Moscovici (Ed.), Psicología social: Vol. 2. Pensamiento y vida social (pp. 379-414). Buenos Aires, Argentina: Paidós.

Paul, I. H. (1973). Cartas a un joven terapeuta: Sobre la conducción en psicoterapia [Letters to Simon: On the conduct of psychotherapy] (I. Pardal, Trans.).Buenos Aires, Argentina: Amorrortu.

Razzouk, D., Mari, J. J., Shirakawa, I., Wainer, J., \& Sigulem, D. (2006). How do experts recognize schizophrenia: The role of the disorganization symptom. Revista Brasileira de Psiquiatria, 28(1), 5-9.doi:10.1590/S151644462006000100003
Restifo, S. (2010). An empirical categorization of psychosocial factors for clinical case formulation and treatment planning. Australasian Psychiatry, 18(3), 210-213. doi:10.3109/10398561003681335

Strauss, A., \& Corbin, J. (1998). Basics of qualitative research: Techniques and procedures for developing grounded theory. Los Angeles, CA: Sage.

Sturmey, P. (Ed.). (2009). Clinical case formulation: Varieties of approaches. Hoboken, NJ: John Wiley \& Sons.

Wampold, B. E. (2015). How important are the common factors in psychotherapy? An update. World Psychiatry, 14(3), 270-277. doi:10.1002/wps.20238

Williams, D. C., \& Levitt, H. M. (2007). A qualitative investigation of eminent therapists' values within psychotherapy: Developing integrative principles for moment-to-moment psychotherapy practice. Journal of Psychotherapy Integration, 17(2), 159-184. doi:10.1037/1053-0479.17.2.159

Francisco Nicolas Di Persia is Professor, Graduate in Psychology (Universidad Nacional de Córdoba, UNC) and $\mathrm{PhD}$ candidate at the UNC, Córdoba, Argentina.

Received: May. 17, 2017

1st Revision: Apr. 26, 2018

Approved: Sep. 25, 2018

How to cite this article:

Di Persia, F. N. (2019). Implicit criteria employed by psychotherapists in clinical case formulation. Paidéia (Ribeirão Preto), 29, e2937. doi: http://dx.doi.org/10.1590/1982-4327e2937 